\title{
ASSESSMENT OF ANTIOXIDANT ACTIVITIES, PHENOL AND FLAVONOID CONTENTS OF DIFFERENT EXTRACTS OF LEAVES, BARK, AND ROOT FROM THE ABUTILON INDICUM (L.) SWEET
}

\author{
SARANYA D ${ }^{1}$, SEKAR J ${ }^{2}$, ADAIKALA RAJ G ${ }^{1 *}$ \\ ${ }^{1}$ Department of Botany, Annamalai University, Cuddalore, Tamil Nadu, India. ${ }^{2}$ Department of Botany, Wing-DDE, Annamalai University, \\ Cuddalore, Tamil Nadu, India. Email: adaikalamvsp@gmail.com
}

Received: 26 October 2017, Revised and Accepted: 01 January 2017

ABSTRACT

Objective: This study antioxidant properties of petroleum ether, chloroform, ethyl acetate, and methanol extracts of Abutilon indicum (L).

Methods: The different extracts of A. indicum leaves, bark, and roots were antioxidant potential using 1,1-diphenyl-2-picryl-hydrazyl, 2, 2-azino-bis3-ethyl benzthiazoline-6-sulfonic acid (ABTS $\left.{ }^{*}\right)$, hydrogen peroxide scavenging, superoxide anions scavenging, hydroxyl radical scavenging, ferric reducing antioxidant power, total antioxidant activity (phosphomolybdic acid) and compare to standard for L- ascorbic acid, butylated hydroxytoluene, and gallic acid.

Results: The highest antioxidant activities were recorded in ethyl acetate extracts of leaves of $A$. indicum followed by roots and bark. Among the plant parts, the ethyl acetate extract of leaves exhibited a significant effect in comparison with other solvent extracts of parts of plant. The ethyl acetate extracts showed the highest total phenol and flavonoid contents in leaves extracts of $A$. indicum. The total phenol $(3.08 \pm 0.06) \mathrm{mg} / \mathrm{ml}$ and flavonoid $(7.16 \pm 0.15) \mathrm{mg} / \mathrm{ml}$ were found to be higher in ethyl acetate extract of $A$. indicum.

Conclusion: The results of the study revealed that the ethyl acetate extract of $A$. indicum leaves can be used for the biological characterization and importance of the compounds identified and creates a platform to screen many bioactive compounds to treat many diseases.

Keywords: Abutilon indicum, Free radical scavenging activity, 1,1-diphenyl-2-picryl-hydrazyl, 2-azino-bis-3-ethyl benzthiazoline-6-sulfonic acid, Ferric reducing antioxidant power.

(c) 2017 The Authors. Published by Innovare Academic Sciences Pvt Ltd. This is an open access article under the CC BY license (http://creativecommons. org/licenses/by/4. 0/) DOI: http://dx.doi.org/10.22159/ajpcr.2017.v10i4.15884

\section{INTRODUCTION}

Free radicals are continuously produced by the body's normal use of oxygen [1]. Oxygen is an element indispensable to life. When cells use oxygen to generate energy, free radicals are produced by the mitochondria. These by-products are generally reactive oxygen species as well as reactive nitrogen species that result from the cellular redox process [2]. Free radicals can be either harmful or helpful to the body. When there is an imbalance in the formation and removal of free radicals then a condition called as oxidative stress is developed in the body. To counteract these free radicals, the body has protective antioxidant mechanisms with the abilities to lower incidence of various human morbidities and mortalities [3].

Antioxidants induce oxidative damage to biomolecules such as lipids, proteins, and DNA. This damage has been implicated in cell disorders and in the development of many diseases including cardiovascular diseases, atherosclerosis, chronic inflammation, and other diseases [4-6]. Antioxidants are the substances that may protect the cells from the oxidative damage caused by free radicals. Natural products have been strong antioxidant activity and they have potential beneficial effects on human health. Many plant species and their active principles have been investigated in the search for natural antioxidants with pharmacological properties $[7,8]$. The studies of medicinal plants not end just with knowledge of their therapeutic use. Various aspects of medicinal plants have to be studied depth for their optimum utilization plant with possible antioxidant activity and to as certain be parameters associated with it.

Abutilon indicum (L.) Sweet belongs to the family Malvaceae and distribute in all parts of tropical and subtropical region of India. It is a perennial shrub, softly tomentose and up to $3 \mathrm{~m}$ in height. Tamil name: Thuthi Sanskrit name: Atibalaa, Telugu name: Duvvena Kayalu. All parts of the plant have been recognized to have medicinal properties. The leaves are ovate, acuminate, toothed, rarely subtrilobate and $2.5 \mathrm{~cm}$ long. The flowers are yellow in color, peduncle jointed above the middle. The petioles are 3.8-7.5 cm long; stipules $9 \mathrm{~mm}$ long; pedicels often 2.5-5 mm long, axillary solitary, jointed very near the top; calyx $12.8 \mathrm{~mm}$ long, divided into middle, lobes ovate, apiculate and corolla $2.5 \mathrm{~cm}$ in diameter, yellow, opening in the evening. The fruits are capsule, densely pubescent, with conspicuous and horizontally spreading beaks. The stems are stout, branched, 1-2 $\mathrm{m}$ tall, pubescent. The seeds are 3-5 mm, reniform, tubercled or minutely stellate-hairy, black or dark brown 5-8.

The traditional method of medicine, the plant used as anthelmintic, anti-inflammatory and antioxidant are useful in urinary and uterine discharges, piles and lumbago [9], jaundice, ulcer, and leprosy. A. indicum leaves are used in the treatment of toothache, lumbago, piles, antifertility, and liver disorders [10]. Root and bark are used as aphrodisiac, antidiabetic and antioxidant activities [11], nervine tonic, and diuretic. The plant extracts and their products for antimicrobial and antioxidant activities have shown that a potential source of novel antibiotic prototypes of higher plants [12].

Hence, the aim of this research was made to study the antioxidant activities of different extracts of leaves, bark, and roots from the A. indicum.

\section{METHODS}

Collection of plant material

The leaf, bark, and root of $A$. indicum (L.) Sweet was collected from Kadavachery village (Lat, $11.24^{\circ} \mathrm{N}$; Long, $79.44^{\circ} \mathrm{E}$ ), Cuddalore 
District, Tamil Nadu, India during the month of January 2014. Herbarium was deposited in the Department of Botany, Annamalai University (Voucher specimen No; AUBOT \#325). The different parts were washed with tap water, then surface sterilized with $10 \%$ sodium hypochloride solution to prevent contamination. The samples were rinsed with distilled water and allowed to shade dried under room temperature followed by oven drying at $50^{\circ} \mathrm{C}$ and then ground into powder using electric blender.

\section{Preparation of extraction}

About $100 \mathrm{~g}$ of powdered material of leaf, bark, and root samples were extracted in a Soxhlet apparatus for $8 \mathrm{hrs}$ with different solvents system such as petroleum ether, chloroform, ethyl acetate, and methanol. The extracts were filtered, pooled, and the solvents were evaporated with the help of rotary evaporator (Heidolph, Germany) under reduced pressure at $40^{\circ} \mathrm{C}$ and the crude extracts were kept at $4{ }^{\circ} \mathrm{C}$ in refrigerator for further analysis.

\section{1,1-diphenyl - 2 - picrylhydrazyl hydrate (DPPH) radical scavenging activity}

The DPPH radical scavenging activities of the different extracts of plant parts were evaluated by the method [13]. Different extracts of various parts samples $(0.1 \mathrm{ml})$ at various concentrations $(125,250,500$ and $1000 \mu \mathrm{g} / \mathrm{ml}$ ) was mixed with $1 \mathrm{ml}$ of $0.2 \mathrm{mM}$ DPPH dissolved in methanol. The reaction mixture was incubated for 20 minutes at $28^{\circ} \mathrm{C}$ in the dark. The control contained all the reagents without the leaf sample and was used as blank. The DPPH radical scavenging activities were determined by measuring the absorbance at $517 \mathrm{~nm}$ using a spectrophotometer (Hitachi U-20). Vitamin C was used as positive control. The antioxidant activities of plant extracts were expressed as inhibitory concentration $\left(\mathrm{IC}_{50}\right)$, which was defined as the concentration $(\mu \mathrm{g} / \mathrm{ml})$ of extracts required to inhibit the formation of DPPH radicals by $50 \%$. The DPPH radical concentration was calculated using the following equation.

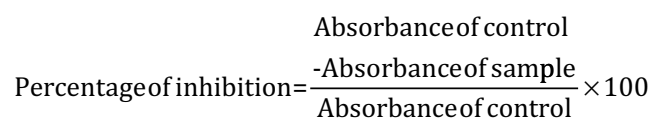

$\mathrm{ABTS}^{++}$scavenging effects (2, 2-Azino-bis-3-ethyl benzthiazoline-6sulfonic acid)

The antioxidant effect of the different crude extracts of $A$. indicum parts was evaluated by the method [14]. ABTS ${ }^{++}$radical cations $\left(\mathrm{ABTS}^{*+}\right)$ were produced by reacting $\mathrm{ABTS}^{*+}$ solution $7 \mathrm{mM}$ with $2.45 \mathrm{mM}$ potassium persulfate. The mixture was incubated at room temperature in the dark for 12-16 hrs to yield a dark-colored solution containing ABTS ${ }^{*+}$ radicals and diluted. The different concentrations of $(125,250,500$ and $1000 \mu \mathrm{g} / \mathrm{ml}$ ) extracts were added to $1 \mathrm{ml}$ of $\mathrm{ABTS}^{\circ+}$ solution. The absorbance was read at $734 \mathrm{~nm}$ after 6 minutes in a spectrophotometer (Hitachi U-20). Butylated hydroxyl tolune (BHT) was used as the standard. Appropriate solvents blanks were run in each assay. All determinations were carried out in triplicate, and the percent of inhibition was calculated using the formula.

\section{Absorbance of control \\ Percentageof inhibition $=\frac{- \text { Absorbanceof sample }}{\text { Absorbance of control }} \times 100$}

\section{Hydrogen peroxide scavenging effects}

The ability of the different extracts of different parts samples were evaluated by the method [15]. A solution of $\mathrm{H}_{2} \mathrm{O}_{2}(40 \mathrm{mM})$ was prepared in phosphate buffer. Different crude extracts at the various concentrations of $(125,250,500$ and $1000 \mu \mathrm{g} / \mathrm{ml})$ were added to $\mathrm{H}_{2} \mathrm{O}_{2}$ solution $(0.6 \mathrm{ml})$ and the total volume was made up to $3 \mathrm{ml}$. The absorbance of the reaction mixture was recorded at $230 \mathrm{~nm}$ in a Spectrophotometer (Hitachi U-20). A blank solution containing phosphate buffer, Vitamin $\mathrm{C}$ was used as positive control. The extent of $\mathrm{H}_{2} \mathrm{O}_{2}$ scavenging of the different extracts were calculated using the formula.
Absorbance of control
Percentageof inhibition $=\frac{- \text { Absorbanceof sample }}{\text { Absorbance of control }} \times 100$

\section{Superoxide anions radical scavenging activity}

The superoxide anions scavenging ability of the different crude extracts were assessed by the method [16]. Superoxide anions were generated in parts samples that contained in $3.0 \mathrm{ml}, 0.02 \mathrm{ml}$ different crude extracts at the concentrations of $(125,250,500$ and $1000 \mu \mathrm{g} / \mathrm{ml}) 0.2 \mathrm{ml}$ of ethylenediaminetetraacetic acid (EDTA), $0.1 \mathrm{ml}$ of NBT, $0.05 \mathrm{ml}$ of riboflavin and $2.64 \mathrm{ml}$ of phosphate buffer. The control tubes were also set up where dimethyl sulfoxide was added instead of the plant extracts. All the tubes were vortexes and the initial optical density was measured at $560 \mathrm{~nm}$ in a spectrophotometer (Hitachi U-20). Vitamin C was used as positive control. The difference in absorbance before and after illumination was indicative of superoxide anion scavenging activities.

Percentage of inhibition $=\frac{- \text { Absorbance of sample }}{\text { Absorbance of control }} \times 100$

\section{Hydroxyl radical scavenging activity}

The hydroxyl radical scavenging from Fenton reaction was quantified using 2'-deoxyribose oxidative degradation as described [17]. The reaction mixture contained $0.1 \mathrm{ml}$ of deoxyribose, $0.1 \mathrm{ml}$ of $\mathrm{FeCl}_{3}, 0.1 \mathrm{ml}$ of EDTA, $0.1 \mathrm{ml}$ of $\mathrm{H}_{2} \mathrm{O}_{2}, 0.1 \mathrm{ml}$ of ascorbate, $0.1 \mathrm{ml}$ of $\mathrm{KH}_{2} \mathrm{PO}_{4}-\mathrm{KOH}$ buffer $(125,250,500$ and $1000 \mu \mathrm{g} / \mathrm{ml})$ of plant extracts of various concentrations in a final volume of $1.0 \mathrm{ml}$. The mixture was incubated at $37^{\circ} \mathrm{C}$ for $1 \mathrm{hr}$. At the end of the incubation period, $1 \mathrm{ml}$ of thiobarbituric acid (TBA) was added and heated at $95^{\circ} \mathrm{C}$ for 20 minutes to develop the color. After cooling, the TBA formation was measured spectrophotometrically (Hitachi U-20) at $532 \mathrm{~nm}$ against an appropriate blank. The hydroxyl radical scavenging activities were determined by comparing the absorbance of the control with samples. The percent TBA production for positive control Vitamin C was fixed at $100 \%$ and the relative percent TBA was calculated for the extracts.

Percentage of inhibition $=\frac{- \text { Absorbance of sample }}{\text { Absorbance of control }} \times 100$

Total antioxidant activity (phosphomolybdic acid method)

The antioxidant activities of the samples parts were evaluated by the transformation of Mo (VI) to Mo (V) to form phosphomolybdenum complex [18]. Aliquots of $0.4 \mathrm{~mL}$ of sample solution were combined in a vial with $4 \mathrm{~mL}$ of reagent solution $(0.6 \mathrm{M}$ sulfuric acid, $28 \mathrm{mM}$ sodium phosphate and $4 \mathrm{Mm}$ ammonium molybdate). The vials were capped and incubated in a water bath at $95^{\circ} \mathrm{C}$ for 90 minutes. After the sample had cooled to room temperature, the absorbance of the mixture was measured at $695 \mathrm{~nm}$ against a blank. The antioxidant activities were express relative to that of Vitamin C.

Absorbance of control
Percentage of inhibition $=\frac{\text {-Absorbance of sample }}{\text { Absorbance of control }} \times 100$

\section{Ferric reducing antioxidant power}

The ferric reducing antioxidant potential of various crude extracts of sample parts as per the method [19]. The samples were mixed with $2.5 \mathrm{ml}$ of $0.2 \mathrm{M}$ phosphate buffer (pH 6.6) and $2.5 \mathrm{ml}$ of $1 \%$ potassium ferric cyanide. After the mixture was incubated at $50^{\circ} \mathrm{C}$ for 20 minutes, $2.5 \mathrm{ml}$ of $10 \%$ trichloroacetic acid, $2.5 \mathrm{ml}$ distilled water, and $0.5 \mathrm{ml}$ of $0.1 \%$ ferric chloride was added and then the absorbance was measured at $700 \mathrm{~nm}$ against a blank. The blank consist of all the reagents without the test sample. The reducing power of gallic acid was also determined 
for a comparison. High absorbance of the reaction mixture indicates strong ferric reducing antioxidant power

\section{Total phenol content}

Total phenolic content was carried out following the Folin-Ciocalteu method described [20]. $1 \mathrm{ml}$ of crude sample extracts solution containing $(1 \mathrm{mg} / \mathrm{ml}$ ) was added volumetric flask. $1 \mathrm{ml}$ of Folin-Ciocalteu reagent and allowed to stand at $22^{\circ} \mathrm{C}$ for 5 minutes; $7.5 \%$ of $0.75 \mathrm{ml}$ of sodium bicarbonate solution was added and mixed thoroughly. The samples were measured spectrophotometrically (Hitachi U-20) at $765 \mathrm{~nm}$ using spectrometer after 90 minutes at $22^{\circ} \mathrm{C}$. The amount of total phenolic was determined as gallic acid and equivalent and expressed as mg gallic acid equivalent (GAE/g).

\section{Total flavonoid content}

The flavonoids content was determined by aluminum trichloride method using catechin as a reference compound [21]. This method based on the formation of a complex flavonoid-aluminum having the absorptive spectrophotometrically (Hitachi U-20) maximum at $415 \mathrm{~nm}$, after remained react at room temperature for 30 minutes. Briefly, $0.5 \mathrm{~mL}$ of each extracts $(1: 10 \mathrm{~g} / \mathrm{mL})$ in methanol was separately mixed with $1.5 \mathrm{~mL}$ of methanol, $0.1 \mathrm{~mL}$ of $10 \%$ aluminum chloride, $0.1 \mathrm{~mL}$ of $1 \mathrm{M}$ potassium acetate, and $2.8 \mathrm{~mL}$ of distilled water. The amount of total flavonoid was determined as $\mathrm{mg} \mathrm{QE} / \mathrm{g}$.

\section{Statistical analysis}

The results are expressed as the mean \pm standard deviation. All statistical analyses were performed using SPSS version 16.0 statistical software (SPSS Inc., Chicago, IL, USA). Student's t-test was performed to determine any significant difference between different extracts for in vitro antioxidant activity assays. Comparison of means for in vivo antioxidant activity assessment was carried out using one-way analysis of variance and Duncan test. $\mathrm{p}<0.05$ was considered statistically significant.

\section{RESULTS}

The petroleum ether, chloroform, ethyl acetate, and methanol leaf extracts of $A$. indicum exhibited the highest DPPH activity. The $\mathrm{IC}_{50}$ values of ethyl acetate extracts of $A$. indicum leaf, bark, root, and Vitamin C (standard) values were ranged from 347.12, 421.34, 438.10, and $204.14 \mu \mathrm{g} / \mathrm{ml}$. The $\mathrm{IC}_{50}$ values of methanol extract of $A$. indicum leaf, bark, root, and Vitamin C values were ranged from 410.14, 498.36, 486.95 , and $198.48 \mu \mathrm{g} / \mathrm{ml}$. The $\mathrm{IC}_{50}$ values of chloroform extract of A. indicum leaf, bark, root, and Vitamin C values were ranged bewteen $426.18,736.80,735.57$, and $192.48 \mu \mathrm{g} / \mathrm{ml}$. The $\mathrm{IC}_{50}$ values of petroleum ether extract of $A$. indicum leaf, bark, and root, and Vitamin C values were ranged from $843.32,954.84,1047.12$, and $209.36 \mu \mathrm{g} / \mathrm{ml}$ is shown in Fig. 1. In this study, different leaf extracts of $A$. indicum exhibited the highest $\mathrm{ABTS}^{\circ+}$ activity. The $\mathrm{IC}_{50}$ values of ethyl acetate extract of A. indicum leaf, bark, root, and standard BHT values were ranged between 295.72, 454.16, 368.42, and $209.36 \mu \mathrm{g} / \mathrm{ml}$, respectively (Fig. 2). The different extracts of leaf from the A. indicum exhibited the highest superoxide anion activity. The $\mathrm{IC}_{50}$ values of ethyl acetate extracts of A. indicum leaf, bark, root, and Vitamin C (standard) values were ranged from 958.09, 1225.46, 1086.23, and $642.59 \mu \mathrm{g} / \mathrm{ml}$. The $\mathrm{IC}_{50}$ values of methanol extract of $A$. indicum leaf, bark, root, and Vitamin $C$ values were ranged from 1052.28, 1368.47, 1124.78, and $656.48 \mu \mathrm{g} / \mathrm{ml}$. The IC $\mathrm{IC}_{50}$ values of chloroform extract of $A$. indicum leaf, bark, root, and Vitamin C values were ranged from 1138.49, 1534.52, 1554.13 , and $656.12 \mu \mathrm{g} / \mathrm{ml}$. The IC ${ }_{50}$ values of petroleum either extract of $A$. indicum leaf, bark, root, and Vitamin $\mathrm{C}$ values were ranged from $1152.56,1885.26,1662.38$, and $684.78 \mu \mathrm{g} / \mathrm{ml}$ is shown Fig. 3.

The petroleum ether, chloroform, ethyl acetate, and ethyl acetate leaf extracts of $A$. indicum exhibited the highest ferric reducing antioxidant power. The $\mathrm{IC}_{50}$ values of ethyl acetate extracts of $A$. indicum leaf, bark, root, and gallic acid (standard) values were ranged from 636.35,

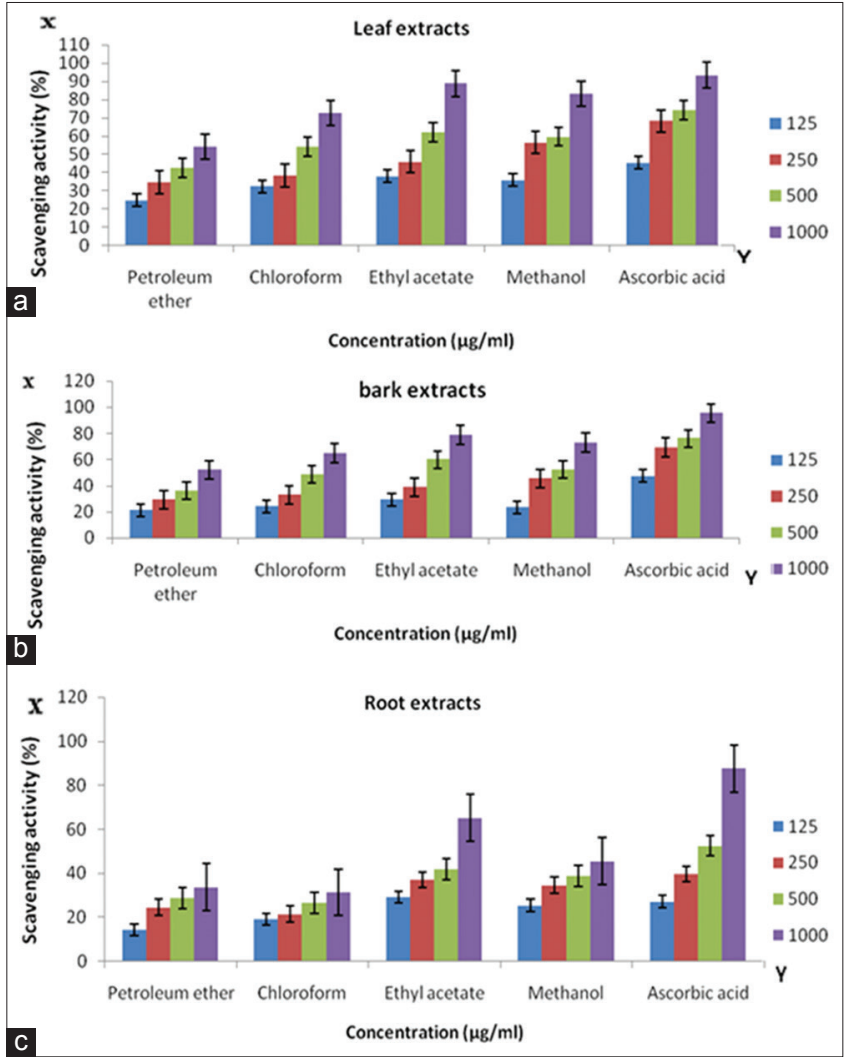

Fig. 1: (a-c) 1, 1-diphenyl -2-picrylhydrazyl hydrate radical scavenging activity of various extracts of Abutilon indicum

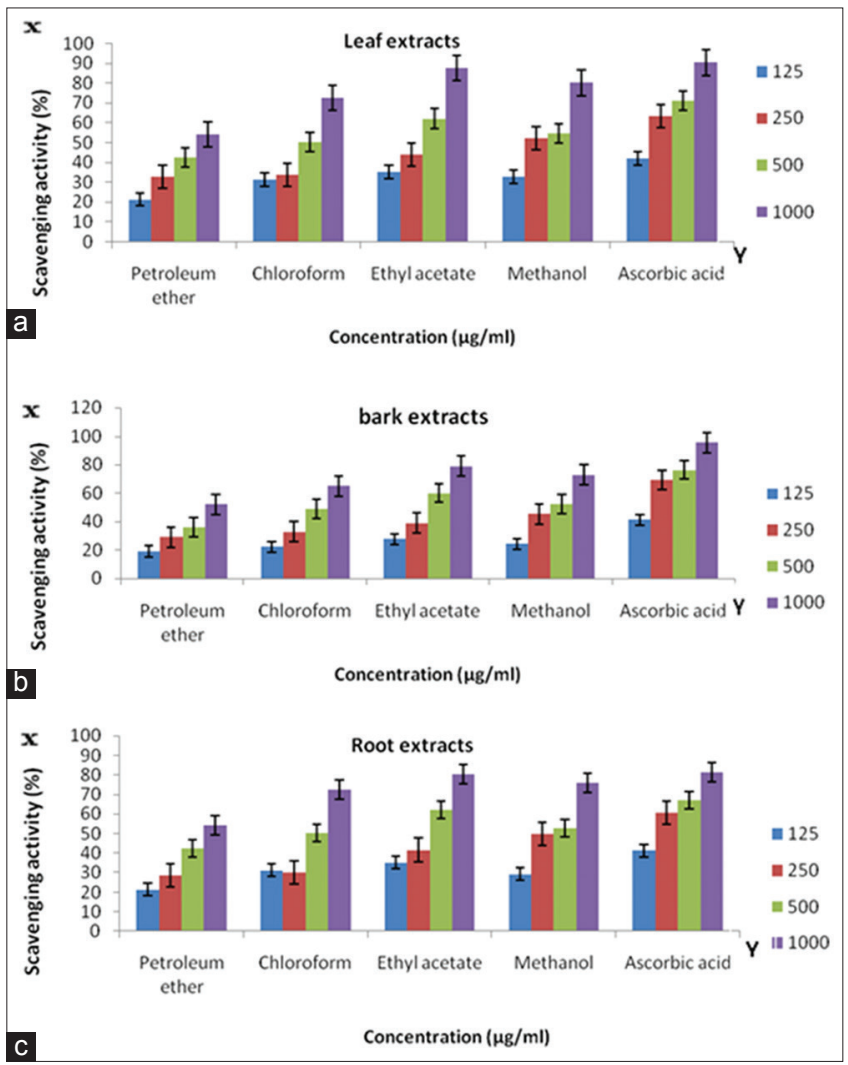

Fig. 2: (a-c) 2, 2-Azino-bis-3-ethyl benzthiazoline-6-sulfonic acid (ABTS ${ }^{\circ}$ ) of various extracts of Abutilon indicum 
934.67, and $494.15 \mu \mathrm{g} / \mathrm{ml}$ is shown in Fig. 4. The different extracts of A. indicum exhibited the highest hydroxyl radical activity. $\mathrm{The}_{\mathrm{IC}}$ values of ethyl acetate extract of $A$. indicum leaf, bark, root, and Vitamin C (standard) values were ranged from 1032.15, 1153.38, 1120.45, and

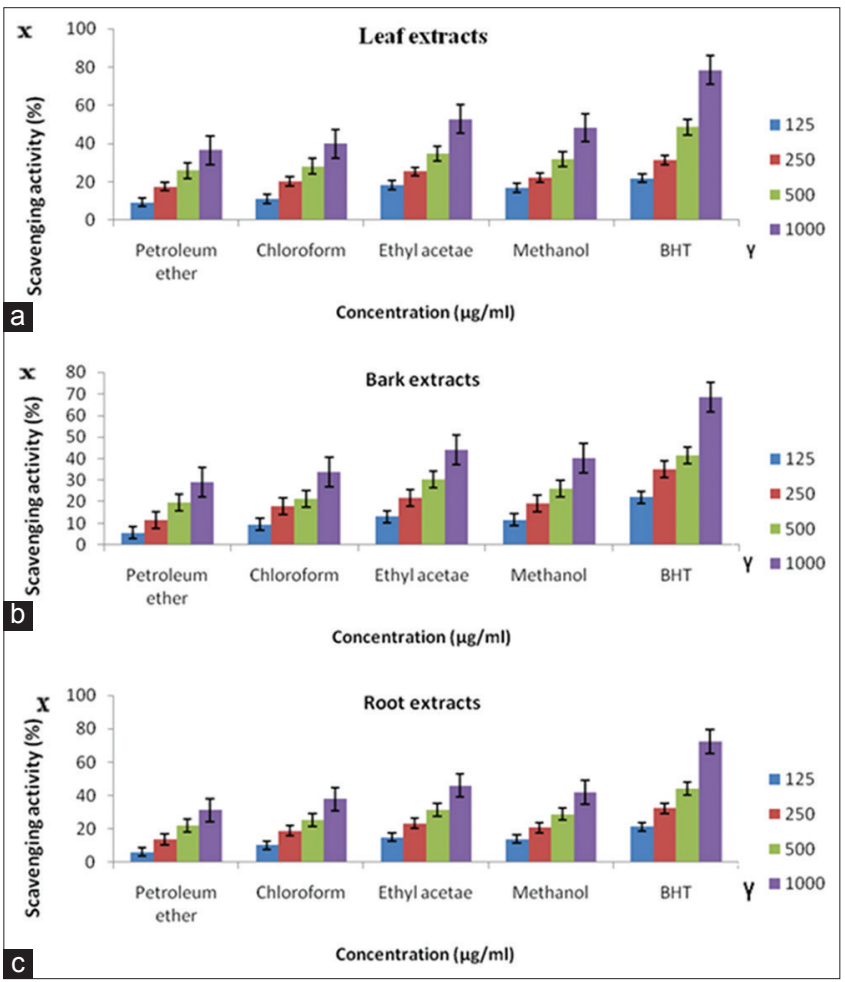

Fig. 3: (a-c) Superoxide anion scavenging activity of different extracts of Abutilon indicum

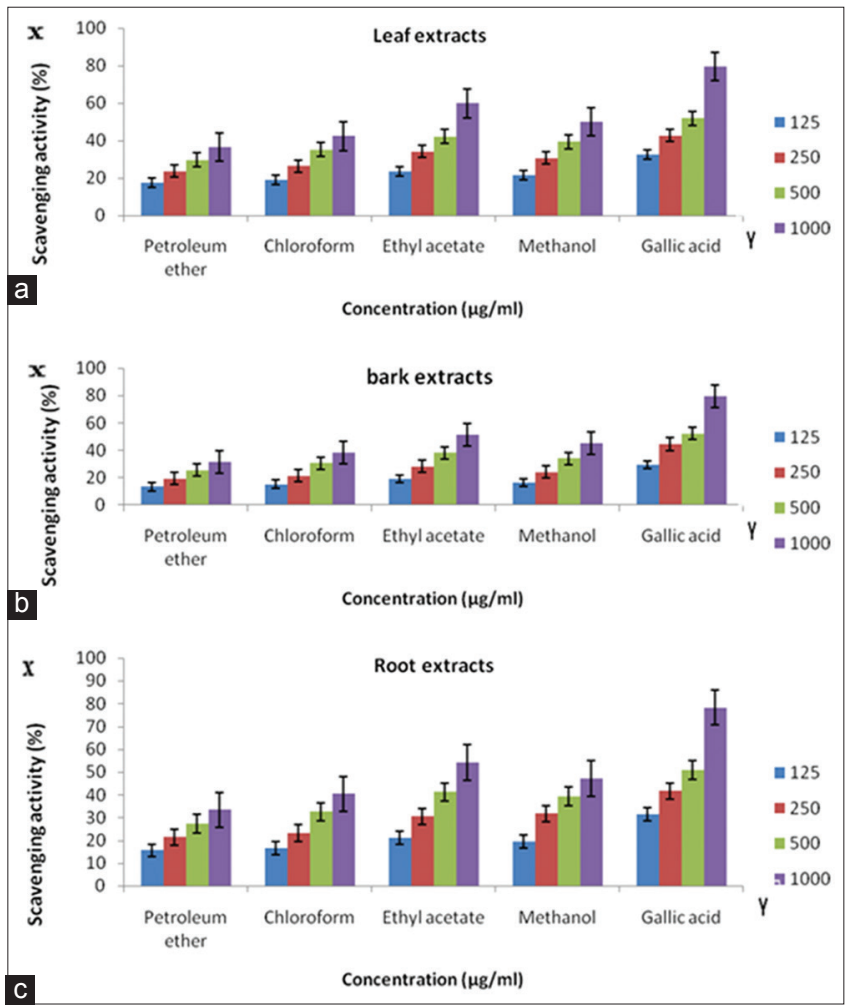

Fig. 4: (a-c) Ferric reducing antioxidant power of various extracts of Abutilon indicum
984.17, 934.67, and $494.15 \mu \mathrm{g} / \mathrm{ml}$ is shown in Fig. 4. The different extracts of $A$. indicum exhibited the highest hydroxyl radical activity. The $\mathrm{IC}_{50}$ values of ethyl acetate extract of $A$. indicum leaf, bark, root, and Vitamin C (standard) values were ranged from 1032.15, 1153.38, 1120.45 , and $945.78 \mu \mathrm{g} / \mathrm{ml}$. The $\mathrm{IC}_{50}$ values of methanol extract of A. indicum leaf, bark, root, and Vitamin $\mathrm{C}$ values were ranged from 1094.76, 1184.31, 1106.38, and $918.42 \mu \mathrm{g} / \mathrm{ml}$. The $\mathrm{IC}_{50}$ values of chloroform extract of A. indicum leaf, bark, root, and Vitamin C values were ranged from $1234.47,1238.53,1212.47$, and $898.42 \mu \mathrm{g} / \mathrm{ml}$. The $\mathrm{IC}_{50}$ values of petroleum ether extract of $A$. indicum leaf, bark, root, and Vitamin C values were ranged from 2034.46, 2158.47, 2132.68, and $930.12 \mu \mathrm{g} / \mathrm{ml}$ is shown in Fig 5. The petroleum ether, chloroform, ethyl acetate, and methanol leaf extracts of $A$. indicum exhibited the highest total antioxidant. The $\mathrm{IC}_{50}$ values of ethyl acetate extract of $A$. indicum leaf, bark, root, and Vitamin C (standard) were 848.12, 986.20, 1037.58, and $657.42 \mu \mathrm{g} / \mathrm{mL}$, respectively (Fig. 6). The different extracts of A. indicum exhibited the highest $\mathrm{H}_{2} \mathrm{O}_{2}$ activity. The $\mathrm{IC}_{50}$ values of ethyl acetate extract of $A$. indicum leaf, bark, root, and Vitamin C (standard) values were found to be $1034.34,1068.76,1164.35$, and $942.39 \mu \mathrm{g} / \mathrm{ml}$. The $\mathrm{IC}_{50}$ values of methanol extract of $A$. indicum leaf, bark, root, and Vitamin C values were found to be 1124.78, 1156.47, 1258.47, and $962.27 \mu \mathrm{g} / \mathrm{ml}$. The $\mathrm{IC}_{50}$ values of chloroform extract of $A$. indicum leaf, bark, root, and Vitamin C values were found to be 1532.36, 1248.86, 1136.83 , and $934.12 \mu \mathrm{g} / \mathrm{ml}$. The $\mathrm{IC}_{50}$ values of petroleum ether extract of $A$. indicum leaf, bark, root, and Vitamin C values were found to be 1051.15, 1074.60, 1168.97, and $429.84 \mu \mathrm{g} / \mathrm{ml}$ is shown in Fig. 7.

Total phenol and flavonoid contents were extracted by organic solvents with different polarities of petroleum ether, chloroform, ethyl acetate, and methanol. The results are presented in Tables 1 and 2 showed the differences in the total phenolic and flavonoid content in different parts of $A$. indicum. The total phenols $(3.08 \pm 0.06) \mu \mathrm{g} / \mathrm{ml} \mathrm{GAE} / \mathrm{g}$ and flavonoids $(7.16 \pm 0.15) \mu \mathrm{g} / \mathrm{ml}$ quercetin equivalent $(\mathrm{QE} / \mathrm{g})$ were found to be higher in ethyl acetate extract of leaves of A. indicum.
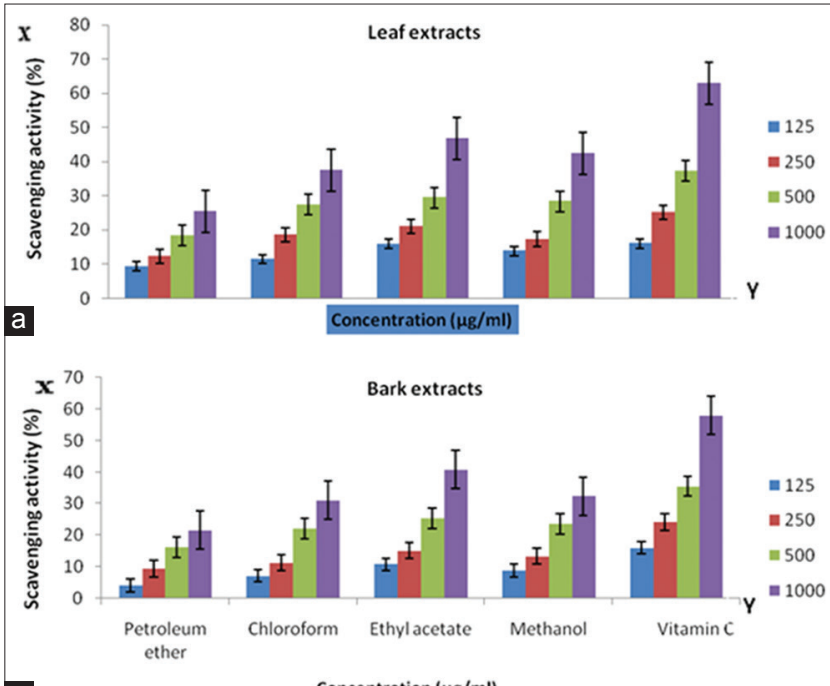

a

Concentration $(\mu \mathrm{g} / \mathrm{ml})$

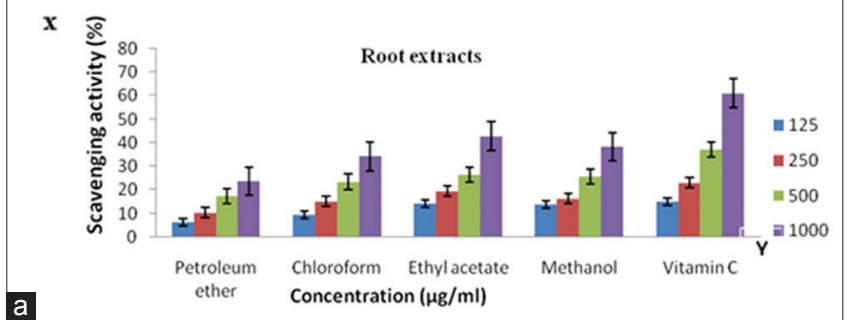

Fig. 5: (a-c) Hydroxyl radical scavenging activity of different extracts of Abutilon indicum 


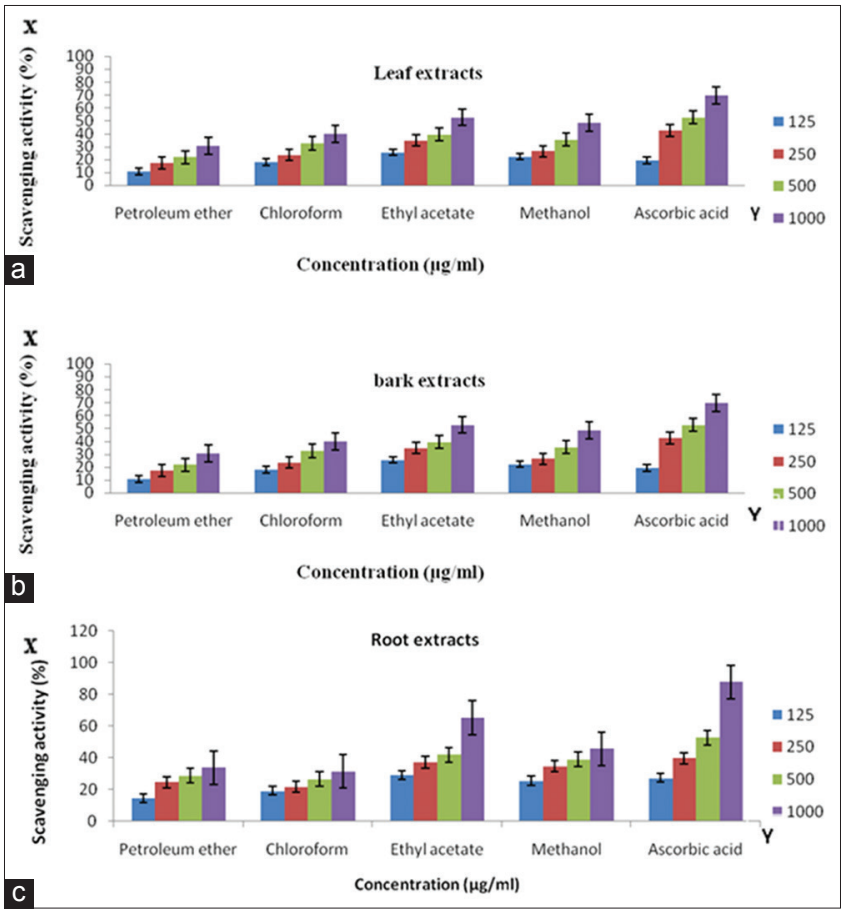

Fig. 6: (a-c) Total antioxidant activity of various extracts of Abutilon indicum

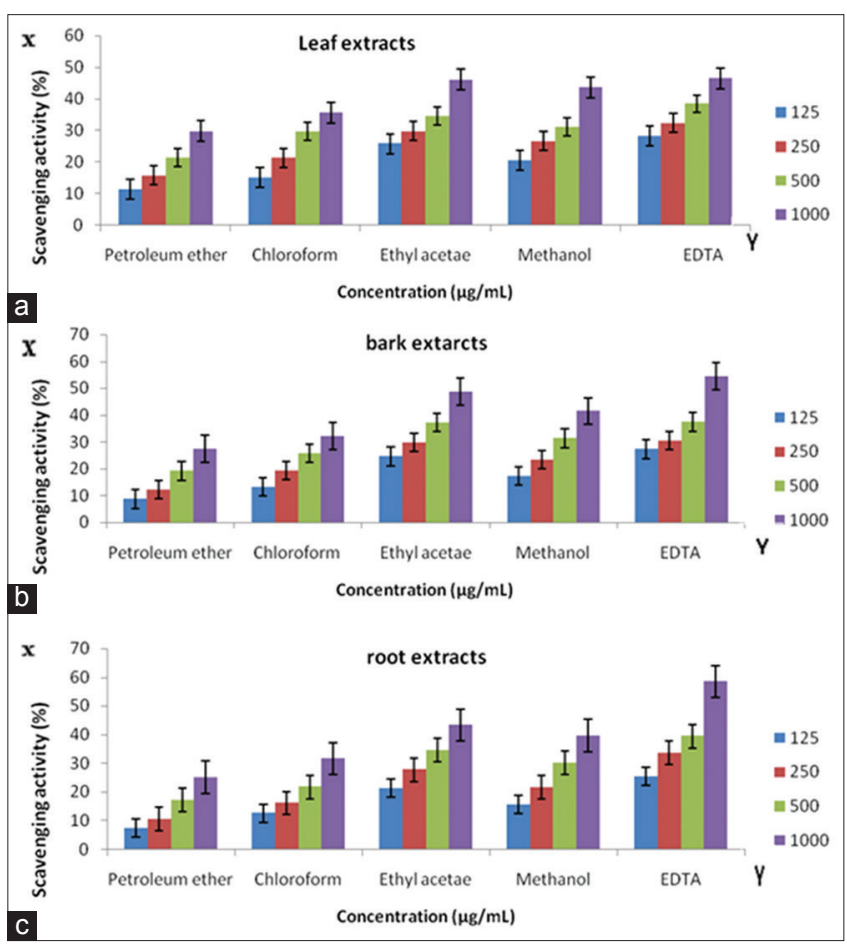

Fig. 7: (a-c) Hydrogen peroxide scavenging activity of various extracts of Abutilon indicum

\section{DISCUSSION}

In this study, petroleum ether, chloroform, ethyl acetate, and methanol extracts of $A$. indicum leaves, stem and root. Among the ethyl acetate extract was found to be the most effective solvent in extraction of antioxidants from the leaves. The ethyl acetate is a widely used and effective solvent for extraction of antioxidant. Ethyl acetate extracts proved to be the most efficient solvent for extraction of antioxidants from Pleurotus florida as the related extract contained the highest amount
Table 1: The total phenol content of different extracts of A. indicum

\begin{tabular}{llll}
\hline \multicolumn{4}{l}{ Total phenol GAE $\mu \mathrm{g} / \mathrm{ml}^{\mathrm{c}}$} \\
\hline Solvents & Leaf & Bark & Root \\
\hline Petroleum ether & $0.64 \pm 0.12^{\mathrm{a}}$ & $0.34 \pm 0.12^{\mathrm{a}}$ & $0.40 \pm 0.05^{\mathrm{a}}$ \\
Chloroform & $0.75 \pm 0.08^{\mathrm{a}}$ & $0.45 \pm 0.31^{\mathrm{a}}$ & $12.05 \pm 0.04^{\mathrm{a}}$ \\
Ethyl acetate & $3.08 \pm 0.06^{\mathrm{b}}$ & $1.64 \pm 0.02^{\mathrm{a}}$ & $14.71 \pm 0.15^{\mathrm{a}}$ \\
Methanol & $2.05 \pm 0.52^{\mathrm{b}}$ & $1.30 \pm 0.28^{\mathrm{ab}}$ & $15.03 \pm 0.96^{\mathrm{b}}$ \\
Gallic acid & $6.82 \pm 0.05^{\mathrm{c}}$ & $3.32 \pm 0.78^{\mathrm{b}}$ & $23.3 \pm 0.41^{\mathrm{c}}$ \\
\hline
\end{tabular}

${ }^{a}$ All the values are mean \pm SD, SD: Standard deviation, ${ }^{\mathrm{a}, \mathrm{b}, \mathrm{c}}$ different letters in the same column indicates significant difference of superscript by DMRT test at $\mathrm{p}<0.05$, ' total phenolic contents were expressed as gallic acid equivalents (GAE/g) samples, GAE: Gallic acid equivalent

Table 2: The total flavonoid content of different extracts of A. indicum

\begin{tabular}{llll}
\hline \multicolumn{4}{l}{ Total flavonoid QE $\boldsymbol{\mu g} / \mathbf{m l}^{\mathrm{C}}$} \\
\hline Solvents & Leaf & Bark & Root \\
\hline Petroleum ether & $3.50 \pm 0.10^{\mathrm{a}}$ & $1.05 \pm 0.18^{\mathrm{a}}$ & $2.80 \pm 0.50^{\mathrm{a}}$ \\
Chloroform & $3.90 \pm 0.18^{\mathrm{a}}$ & $0.37 \pm 0.25^{\mathrm{a}}$ & $2.49 \pm 0.04^{\mathrm{a}}$ \\
Ethyl acetate & $7.16 \pm 0.15^{\mathrm{ab}}$ & $5.41 \pm 0.12^{\mathrm{a}}$ & $6.26 \pm 0.09^{\mathrm{ab}}$ \\
Methanol & $6.89 \pm 0.04^{\mathrm{b}}$ & $4.19 \pm 0.21^{\mathrm{a}}$ & $5.43 \pm 0.21^{\mathrm{a}}$ \\
Quercetin & $11.12 \pm 0.09^{\mathrm{c}}$ & $7.45 \pm 0.25^{\mathrm{c}}$ & $9.26 \pm 0.03^{\mathrm{c}}$ \\
\hline
\end{tabular}

${ }^{a}$ All the values are mean \pm SD, SD: Standard deviation, ${ }^{a, b, c}$ different letters in the same column indicates significant difference of superscript by DMRT test at $\mathrm{p}<0.05$, ' total flavanoid contents were expressed as quercetin equivalents $(\mathrm{QE} / \mathrm{g})$ samples

of phenolic compounds and also exhibited the strongest antioxidant capacity in all the assays [22]. This study petroleum ether, chloroform, ethyl acetate, and methanol leaf extracts of $A$. indicum exhibited the highest DPPH activity. Similar results were observed Nayak et al. [23] coincide the results DPPH assay this process changes the characteristic purple color of the DPPH solution to yellowish. The colorimatic method involves decrease in absorbancy by increasing activity of the plant extract to neutralizing free radicals generated by the DPPH. A. indicum and Paederia foetida both shows decrease in absorbancy but $A$. indicum has higher power of inhibition compared to $P$. foetida as former showed the $\mathrm{IC}_{50}$ value $52 \mu \mathrm{g} / \mathrm{ml}$ and later shows $\mathrm{IC}_{50}$ value $98 \mu \mathrm{g} / \mathrm{mL}$. Kumar et al. [24] reported that in vitro antioxidant activity of methanolic extract of aerial parts of Salvia splendens had shown very significant DPPH radical scavenging, hydrogen peroxide scavenging, and superoxide anion scavenging activity compared to standard.

In this study, petroleum ether, chloroform, ethyl acetate, and methanol leaf extracts of $A$. indicum exhibited the highest ABTS $^{*+}$ activity. Jamuna and Ravishankar [25] reported that the chloroform and ethyl acetate extracts of root part of Hypochaeris radicata exhibited higher ABTS $^{*+}$ radical scavenging activity. On the other hand, in our results, the ABTS ${ }^{*+}$ activity of leaf, bark, and root extracts of A. indicum was shown in the order of ethyl acetate $>$ methanol $>$ chloroform $>$ petroleum ether. The results are in agreement with that of the previous reports of Whistler and BeMiller [26]. Chen et al. [27] studied the antioxidant activities of five medicinal plants, viz., Ampelopsis sinica, Ampelopsis humiliforlia, Potentilla freyniana, Selaginella labordei, and Chrysanthemum multiflorum. Extracts from all five of the plants inhibited xanthine oxidase and lipoxygenase activities and were scavengers of the $\mathrm{ABTS}^{*+}$ radical cation using the trolox equivalent antioxidant capacity assay. Surveswaran et al. [28] reported that 133 plants belongs to the 64 families were collected and their extracts were tested for their antioxidant capacity. DPPH radical scavenging, $\mathrm{ABTS}^{*+}$ radical scavenging and ferric reducing antioxidant power activity. The total phenol contents were measured in each plant tissue, as well as individual phenolics to identify the compounds potentially responsible for the strongest antioxidant activities. 
The petroleum ether, chloroform, ethyl acetate, and methanol leaf extracts of $A$. indicum exhibited the highest superoxide anion activity. Super oxide is a highly reactive molecule that reacts with various substances produced though the metabolic process, superoxide dismutase enzyme present in aerobic and anaerobic organisms catalyses the breakdown of superoxide radical [29]. The superoxide scavenging ability of plant extract might primarily be due to the presence of flavonoids [30]. Superoxide anion is one of the most representative free radicals. In cellular oxidation reactions, superoxide radicals have their initial effects magnified because they produce other kinds of celldamaging free radicals and oxidizing agents, e.g., hydroxyl radical [31]. Antioxidant activity of methanolic extract of $A$. indicum leaves was investigated for its free radical scavenging activity by determining the nitric oxide and super oxide radical scavenging activity.

In this study, petroleum ether, chloroform, ethyl acetate, and methanol leaf extracts of $A$. indicum exhibited the highest ferric reducing antioxidant power. The ferric reducing antioxidant power (FRAP) assay showed reducing powers of the fraction in order of butanol $>$ ethyl acetate $>$ chloroform $>n$-hexane or Acaulon muticum, respectively. The reaction kinetics with this free radical indicated the presence of both slow reacting and fast reacting antioxidant components in the extracts of both plants. Abutilon species are potential sources of natural antioxidants [32]. Ahmed and Urooj [33] suggested that the antioxidant activity of leaf extracts of $A$. indicum was evaluated to explore new bioactive compatibles with least associated side effects. The methanol extracts were prepared and screened for in vitro using FRAP. The reducing power of methanolic leaf extract was markedly increase by increasing concentration. The results indicated a strong antioxidant activity.

The petroleum ether, chloroform, ethyl acetate, and methanol leaf extracts of $A$. indicum exhibited the highest total antioxidant. Ashafa et al. [34] have reported the total antioxidant activity of the acetone extracts of Felicia muricata. It was found to be a good total antioxidant activity due to the presence of gallic acid. The antioxidant activity of methanolic extracts from the leaves and stem of Mollugo nudicaulis were by quantifying phenolic, flavonoids contents and by antioxidant assays such as DPPH and ferric reducing power assays. The results indicate that presence of significant quantities of total phenolics, flavonoids, and antioxidant activity [35].

This study petroleum ether, chloroform, ethyl acetate, and methanol leaf extracts of $A$. indicum exhibited the highest hydroxyl radical activity. The $\mathrm{IC}_{50}$ values of ethyl acetate extract of $A$. indicum leaf, bark, root, and Vitamin C (standard) were 1032.15, 1153.38, 1120.45, and $945.78 \mu \mathrm{g} / \mathrm{ml}$, respectively. Hydroxyl radical is highly reactive oxygen, centered radical, formed from the reaction of various hydroperoxides with transition metal ions. It attacks proteins, DNA, polyunsaturated fatty acid membranes and most biological molecule it contacts and is known to be capable of abstracting hydrogen atoms from membrane lipids and brings about peroxide reaction of lipids [36].

The different extracts of $A$. indicum exhibit the highest $\mathrm{H}_{2} \mathrm{O}_{2}$ activity. The IC $\mathrm{IC}_{50}$ values of ethyl acetate extract of $A$. indicum leaf, bark, root, and Vitamin C (standard) were found to be 1034.34, 1068.76, 1164.35, and $942.39 \mu \mathrm{g} / \mathrm{ml}$, respectively. Dhruti [37] reported that the antioxidant activity of the methanolic and aqueous extracts of Martynia annua leaves was evaluated by several in vitro systems of assay namely, reducing power assay, DPPH radical scavenging activity, nitric oxide scavenging activity, $\mathrm{H}_{2} \mathrm{O}_{2}$ radical scavenging activity, superoxide radical scavenging, hydroxyl radical-scavenging activity, and total antioxidant capacity. The total phenolic content was measured by Folin-Ciocalteau reagent. The antioxidant property depends on concentration and increased with increasing amount of the extract. The free radical scavenging and antioxidant activity may be attributed to the presence of phenolic and flavonoid compounds present in the extract. The results showed that the ethyl acetate extract exhibited higher antioxidant activity than the methanol, chloroform, and hexane extracts.
The total phenols $(3.08 \pm 0.06) \mu \mathrm{g} / \mathrm{ml} \mathrm{GAE} / \mathrm{g}$ and flavonoids (7.16 \pm 0.15$) \mu \mathrm{g} / \mathrm{ml}$ quercetin equivalent $(\mathrm{QE} / \mathrm{g})$ were found to be higher in ethyl acetate extract of leaves of $A$. indicum. The phenolic compounds are known as powerful chain breaking antioxidant. Phenols are very important plant constituents because of their scavenging ability due to their hydroxyl group and may contribute directly to antioxidative action [38]. It is suggest that polyphenolic compounds have inhibitory effects on mutagenesis and carcinogenesis in humans [39]. Similar results were observed total phenolic content of $154.81 \mathrm{mg}$ $\mathrm{GAE} / \mathrm{g}$ in the water extracts and $169.06 \mathrm{mg} \mathrm{GAE} / \mathrm{g}$ in methanol extract leaves of Teucrium montanum L. Var. montanum, F. supinum of leaves was reported [40]. The leaf ethyl acetate extract of T. montanum had flavonoid content of $58.48 \mathrm{mg}$ RU/g. Flavonoids are potent antioxidants and free radical scavengers, which prevent oxidative cell damage and have strong anticancer activity [41]. The leaf extracts exhibit a much higher total phenol and flavonoid contents when compared to the bark and root. These results probably explain the high antioxidant activities found in aerial parts of leaves and stem and are in agreement with previous findings reported in other medicinal plants [42].

\section{CONCLUSION}

The natural products proved less side effects and cure diseases effectively from ancient period. In this study, the crude extracts of A. indicum leaves, bark, and root. In that way, medicinal plant, $A$. indicum leaves can be used as elute novel active compounds from the medicinal plants which may create a new way to treat many incurable diseases.

\section{ACKNOWLEDGMENT}

Authors thank the Professor and Head Department of Botany, Annamalai University, for having provided laboratory facilities.

\section{REFERENCES}

1. Tiwari AK. Antioxidants: New-generation therapeutic base for treatment of polygenic disorders. Curr Sci 2004;86(8):1092-102.

2. Sivanandham V. Free radicals in health and diseases. Pharmacol Online 2011;1:1062-77.

3. Shinde A, Ganu J, Naik P. Effect of free radicals and antioxidants on oxidative stress. J Dent Allied Sci 2012;1(2):63-6.

4. Valko M, Leibfritz D, Moncol J, Cronin MT, Mazur M, Telser J. Free radicals and antioxidants in normal physiological functions and human disease. Int J Biochem Cell Biol 2007;39(1):44-84

5. Ferreira IC, Barros L, Abreu RM. Antioxidants in wild mushrooms. Curr Med Chem 2009;16(12):1543-60.

6. Cavar S, Kovac F, Maksimovic M. Evaluation of the antioxidant activity of a series of 4-methylcoumarins using different testing methods. Food Chem 2012;133:930-7.

7. Singh R, Baichheti R, Saini CK, Singh U. In vitro antioxidant activity of Canna indica extracts using different solvent system. Asian J Pharm Clin Res 2016;9(6):1-4.

8. Vinoth B, Manivasagaperumal R, Prakash P. Free radical scavenging potential of different extracts from Azima tetracantha Lam. Int J Res Ayurveda Pharm 2015;6(1):131-7.

9. Porchezhian E, Ansari SH. Effect of liquid extract from fresh Abutilon indicum leaves and Allium cepa bulbs on paracetamol and carbontetrachloride induced hepatotoxicity. Pharmazie 2000;55(9):702-3.

10. Anyensu ES. Medicinal Plants of West Africa. Algonac, Michigan: Publications Inc.; 1978. p. 1-10.

11. Lakshmayya S, Nelluri NR, Kumar P, Agarwal NK, Gouda TS, Setty SR. Phytochemical and pharmacological evaluation of leaves of Abutilon indicum. Indian J Tradit Knowl 2003;2(1):79-83.

12. Afolayan AJ. Extracts from the shoots of Arctotis artotoides inhibit the growth of bacteria and fungi. Pharm Biol 2003;41:22-5.

13. Blois MS. Antioxidant determinations by the use of a stable free radical. Nature 1958;29:1199-200

14. Re R, Pellegrini N, Proteggente A, Pannala A, Yang M, Rice-Evans C. Antioxidant activity applying an improved ABTS radical cation decolorization assay. Free Radic Biol Med 1999;26(9-10):1231-7.

15. Ruch RJ, Cheng SJ, Klaunig JE. Prevention of cytotoxicity and inhibition of intercellular communication by antioxidant catechins isolated from Chinese green tea. Carcinogenesis 1989;10(6):1003-8. 
16. Winterbourn CC, Hawkins RE, Brian M, Carrell RW. The estimation of red cell superoxide dismutase activity. J Lab Clin Med 1975;85(2):337-41.

17. Elizabeth K, Rao MN. Oxygen radical scavenging activity of curcumin. Int J Pharm 1990;58(13):237-40.

18. Prieto P, Pineda M, Aguilar M. Spectrosphotometric quantization of antioxidant capacity through the formation of a phospomolybdenum complex: Specific application to the determination of Vitamin E. Anal Biochem 1999;269(2):337-41.

19. Oyaizu M. Studies on product of browning reaction prepared from glucose amine. J Nutr 1986;44:307-15.

20. Singleton VL, Rossi JA. Colorimetry of total phenolics with phosphomolybdic-phosphotungstic acid reagents. Am J Enol Vitic 1965;16:144-58.

21. Chang C, Yang M, Wen H, Chern J. Estimation of total flavonoid content in propolis by two complementary colorimetric methods. J Food Drug Anal 2002;10:178-82.

22. Menaga D, Rajakumar S, Ayyasamy PM. Free radical scavenging activity of methanolic extract of Pleurotus florida mushroom. Int J Pharm Pharm Sci 2013;5(4):601-6.

23. Nayak R, Panda A, Samanta L, Sahoo S. Phytochemical analysis of antioxidants from Abutilon indicum L. and Paederia foetida L. Supported by TLC, FTIR and NMR studies. Int J Sci Res 2015;4(5):2319-24.

24. Kumar PM, Sasmal D, Mazumder PM. The antihyperglycemic effect of aerial parts of Salvia splendens (scarlet sage) in streptozotocin-induced diabetic-rats. Pharmacognosy Res 2010;2(3):190-4.

25. Jamuna BA, Ravishankar RV. In-vitro evaluation of antioxidant and antibacterial activities of Rotula aquatica and Ancistrocladus heyneanus: Antioxidant and antimicrobial activity of medicinal plants. J Pharm Res 2013;6(2):313-7.

26. Whistler RL, BeMiller JN. Industrial Gums: Polysaccharides and Their Derivatives. London, UK: Academic Press; 1993.

27. Chen K, Plumb GW, Bennett RN, Bao Y. Antioxidant activities of extracts from five anti-viral medicinal plants. J Ethnopharmacol 2005;96(1-2):201-5.

28. Surveswaran S, Cai Y, Corke H, Sun M. Phytochemical screening and biological activities of the oil components of Prunus domestica. Food Chem 2007;102:938-53
29. Shirwaikar A, Punitha IS. Antioxidant studies on the methanol stem extract of Coscinium fenestratum. Natural Product Sci 2007;13(1):40-5.

30. Zheng W, Wang SY. Antioxidant activity and phenolic compounds in selected herbs. J Agric Food Chem 2001;49(11):5165-70.

31. Finkel T, Holbrook NJ. Oxidants, oxidative stress and the biology of ageing. Nature 2000;408(6809):239-47.

32. Yasmin S, Kashmiri MA, Ahmad I, Adnan A, Ahmad M. Chemical constituents of Abutilon indicum Linn. Pharm Biol 2008;46:673-6.

33. Ahmed F, Urooj A. Glucose-lowering, hepatoprotective and hypolipidemic activities of stem bark of Ficus racemosa in streptozotocin induced diabetic rats. J Young Pharm 2009;1:160-4.

34. Ashafa AO, Grierson DS, Afolayan AJ. In vitro antioxidant activity of extracts from the leaves of Felicia muricata thumb an underutilized medicinal plants in the Eastern Cape, Province of South Africa. Afr J Tradit Complement Altern Med 2010;7:294-302.

35. Archana I, Vijayalakshmi K. Preliminary phytochemical screening and in vitro free radical scavenging activity of root extracts of Glycyrrhiza glabra L. Asian J Pharm Clin Res 2016;9(6):1-6.

36. Lie FS, Jieh HT, Je HC, Chih YC, Chiu PL. Antioxidant properties of extracts from medicinal plants popularly used in Taiwan. Int J Appl Sci Eng 2005;3(3):195-202.

37. Dhruti N. Antioxidant activities of methanolic and aqueous extracts from leaves of Martynia annua Linn. Pharmacognosy J 2009;1(4):288-90.

38. Hatano T, Edamatsu R, Mori A. Effects of interaction of tannins with coexisting substances. Chem Pharm Bull 1989;37:2016-21.

39. Sawant O, Kadam J, Ghosh R. In-vitro free radical scavenging and antioxidant activity of Adiantum lunulactum. J Herb Med Toxicol 2009;3:39-44.

40. Stankovic MS, Neda N, Topuzovic M, Solujic S. Total phenolic content, flavonoid concentrations and antioxidant activity, of the whole plant and plant parts extracts from Teucrium montanum L. Var. montanum, F. Supinum (L.) Reichenb. Biotechnol Biotechnol Equip 2011;25(1):2222-7.

41. Shahidi F, Wanasundara PK. Phenolic antioxidants. Crit Rev Food Sci Nutr 1992;32:67-103.

42. Tosun M, Ercisli S, Sengul M, Ozer H, Polat T, Ozturk E. Antioxidant properties and total phenolic content of eight Salvia species from Turkey. Biol Res 2009;42(2):175-81. 